Article

\title{
Anti-Acne Vulgaris Potential of the Ethanolic Extract of Mesua ferrea L. Flowers
}

\author{
Wongnapa Nakyai ${ }^{1, *}$, Wachirachai Pabuprapap ${ }^{1}$ (D), Wichuda Sroimee ${ }^{2}$, Vachiraporn Ajavakom ${ }^{1}$, \\ Boon-ek Yingyongnarongkul ${ }^{1}$ and Apichart Suksamrarn ${ }^{1}$ \\ 1 Department of Chemistry and Center of Excellence for Innovation in Chemistry, Faculty of Science, \\ Ramkhamhaeng University, Bangkok 10240, Thailand; wachirachai7@gmail.com (W.P.); \\ Vachiraporn.a@rumail.ru.ac.th (V.A.); boon-ek.y@rumail.ru.ac.th (B.-e.Y.); s_apichart@ru.ac.th (A.S.) \\ 2 College of Integrative Medicine, Dhurakij Pundit University, Bangkok 10210, Thailand; \\ Wichuda.sro@dpu.ac.th \\ * Correspondence: wongnapa_n@rumail.ru.ac.th or wongnapanakyai@hotmail.co.th; Tel.: +66-2310-8400
}

Citation: Nakyai, W.; Pabuprapap, W.; Sroimee, W.; Ajavakom, V.;

Yingyongnarongkul, B.-e.;

Suksamrarn, A. Anti-Acne Vulgaris Potential of the Ethanolic Extract of Mesua ferrea L. Flowers. Cosmetics 2021, 8, 107. https://doi.org/ $10.3390 /$ cosmetics 8040107

Academic Editor: Kazuhisa Maeda

Received: 5 October 2021

Accepted: 8 November 2021

Published: 12 November 2021

Publisher's Note: MDPI stays neutral with regard to jurisdictional claims in published maps and institutional affiliations.

Copyright: (c) 2021 by the authors. Licensee MDPI, Basel, Switzerland. This article is an open access article distributed under the terms and conditions of the Creative Commons Attribution (CC BY) license (https:// creativecommons.org/licenses/by/ $4.0 /)$.

\begin{abstract}
Acne vulgaris is a common chronic inflammatory skin disease. In the present study, we reported the anti-acne vulgaris effect of the Mesua ferrea ( $M$. ferrea) flower extract. The extract was evaluated for three anti-acne-causing bacteria properties including Cutibacterium acnes (C. acnes), Staphylococcus epidermidis (S. epidermidis) and Staphylococcus aureus (S. aureus). The results indicated that the $M$. ferrea flower extract could be considered as the bactericidal agent against S. epidermidis and S. aureus with MIC values of 0.78 and $6.25 \mathrm{mg} \mathrm{mL}^{-1}$ and MBC values of 1.56 and $12.50 \mathrm{mg} \mathrm{mL}^{-1}$ and the bacteriostatic agent against $C$. acnes with MIC and MBC values of 3.12 and $25.00 \mathrm{mg} \mathrm{mL}^{-1}$, respectively. The extract at a concentration of $25 \mu \mathrm{g} \mathrm{mL}^{-1}$ also presented potent anti-inflammatory activity with a significant decrease of nitric oxide (NO) and tumor necrosis factor (TNF)- $\alpha$ productions in RAW 264.7 macrophage cells stimulated by LPS. In addition, the extract showed moderate to weak anti-oxidative capacities against DPPH, ABTS, FRAP and NO assays and also showed weak antityrosinase activity. M. ferrea flower extract may serve as the alternative natural anti-acne formulations.
\end{abstract}

Keywords: Mesua ferrea; anti-acne; anti-bacteria; anti-inflammation; anti-oxidant; anti-tyrosinase

\section{Introduction}

Acne vulgaris, also known as acne, is one of the most common dermatological diseases, which is a chronic inflammatory pilosebaceous skin disorder that affects the face, chest and back. This condition decides about $85 \%$ of people, especially prevalent among young adolescents [1]. Acne is associated with the increase of sebum production by overactive oil glands, the hyperkeratinization by blocking skin pores, the successive release of skin inflammatory mediators and the bacterial colonization in the follicles leading to the carrying of commensal skin microorganisms [2]. Three main Gram-positive bacteria, Cutibacterium acnes (formerly Propionibacterium acnes), Staphylococcus epidermidis and Staphylococcus aureus, are involved in the bacterial colonization of the follicle. C. acnes plays an important role in the pathogenesis and progression of acne [3], which could activate the immune system and triggering an inflammatory cascade in infected cells. As an immunostimulant, C. acnes is responsible for invading pathogens by releasing free radicals and inflammatory mediators such as nitric oxide (NO) produced by inducible NO synthase (iNOS) and proinflammatory cytokines including tumor necrosis factor (TNF)- $\alpha$, resulted in the modulation of inflammatory gene expression that is important in the immune response involved in the inflammatory skin disorder, including acne [4-7]. In addition, S. epidermidis and S. aureus involve in acne progression by causes a majority infection of the pilosebaceous unit. These bacteria also produce biofilm formation, leading to anaerobic condition to promote proliferation of $C$. acnes. This phenomenon provokes an innate immune reaction, trigger inflammation of acne $[3,6]$. 
As therapeutic agents for acne vulgaris, anti-acne agents including retinoic acid and derivatives, benzoyl peroxide, salicylic acid, azelaic acid and vitamins $B$ and $C$ and antibiotics including macrolides clindamycin and tetracyclines, are generally used in the treatment of acne. However, the continued use of these chemical-based agents could have side effects including skin irritation, lightheadedness, dizziness and tinnitus. In addition, laser and light-based therapy were alternatives for acne treatment with improvements in acne scarring and skin texture. Nonetheless, these approaches caused high costs and pains. To overcome the adverse effects of these agents, the development of novel anti-acne agents with high anti-bacterial and anti-inflammatory activities and fewer side effects seems to be necessary. Traditional therapeutics like natural products have been used as alternative medicine in acne treatment. Therefore, many potential plants and plant extracts are currently used as anti-acne agents, such as Aloe vera, Allium cepa, Centella asiatica and tea tree oil [8-12].

Mesua ferrea L., known in Thai as Bunnak, belongs to the Calophyllaceae family [13]. It is widely distributed throughout India, Sri Lanka, Myanmar, Indo-China, Thailand, Singapore and Malaysia. In Thailand, the barks are traditionally used for the treatment of dysentery and vomiting. The seeds are used as an aromatic and a wound healer, while the flowers are used as expectorant, carminative, cordial and blood tonic agents in traditional Thai medicine $[14,15]$. This plant species showed a wide range of various phytochemical constituents, including coumarins, xanthones, triterpenoids, anthraquinones and flavonoids [16-20]. The plant has shown various pharmacological activities including anti-oxidant, anti-spasmodic, anti-inflammatory, anti-cancer, anti-ulcer, anti-diabetic, antiarthritic, anti-microbial, anti-venom, anti-convulsant, anti-hemorrhoid, central nervous system depressant, $\alpha$-amylase inhibitory, immunomodulatory and hormone balancing, hepatoprotective, analgesic, and diuretic activities [21-23].

As part of our ongoing work on alternative anti-acne agents, the search of natural products possessing is not focused only on inhibition activities against acne bacterial strains, but also on anti-inflammatory potentials, which may have topical applications in the treatment of acne vulgaris. Despite many studies on natural anti-acne agents, there have been few reports on the anti-acne effect of $M$. ferrea. Therefore, this study aimed to investigate the potential application of the extract of $M$. ferrea flowers on the inhibitory activities against acne-causing bacteria. The anti-inflammatory activities of the extract through the inhibition of NO and TNF- $\alpha$ were evaluated. Moreover, the anti-oxidative and anti-tyrosinase activities of the extract were also investigated.

\section{Materials and Methods}

\subsection{Chemicals and Reagents}

All chemicals and solvents used were supplied by Merck (Darmstadt, Germany), TCI (Tokyo, Japan), or Sigma-Aldrich (St. Louis, MO, USA). Lipopolysaccharide (LPS) (from Escherichia coli serotype O111:B4) and tyrosinase from mushroom (EC 1.14.18.1) were purchased from Sigma-Aldrich (St. Louis, MO, USA).

\subsection{Plant Material}

The flowers of Mesua ferrea were purchased from Chaokrompoe Herbal Store, Bangkok, Thailand in January 2021, and the plant species was identified by Assoc. Prof. Nopporn Dumrongsiri, Ramkhamhaeng University. A voucher specimen is deposited at the Faculty of Science, Ramkhamhaeng University, Thailand (Apichart Suksamrarn, No. 102).

\subsection{Preparation of $M$. ferrea Flower Extract}

The air-dried flowers of $M$. ferrea were milled and macerated with $95 \%(v / v)$ ethanol at room temperature for $72 \mathrm{~h}$. The extraction procedure was repeated for 5 times; the combined solution was filtered and the solvent was evaporated under reduced pressure at $40-45^{\circ} \mathrm{C}$. The residue was freeze-dried to remove remaining solvent and the extract was stored at $-20^{\circ} \mathrm{C}$ until further analysis. 


\subsection{Total Phenolic Contents}

The total phenolic content of the extract was determined by using Folin-Ciocalteu assay [24] with slight modifications. In brief, a solution of $130 \mu \mathrm{L}$ of DI water, $10 \mu \mathrm{L}$ of the test extract and $10 \mu \mathrm{L}$ of Folin-Ciocalteu reagent was mixed and after $5 \mathrm{~min}, 100 \mu \mathrm{L}$ of $7 \%$ $(w / v) \mathrm{Na}_{2} \mathrm{CO}_{3}$ was added. The solution was left in the dark for $30 \mathrm{~min}$, and the absorbance was measured with a microplate reader (Sunrise, Opfikon, Switzerland) at $734 \mathrm{~nm}$. The total phenolic content was calculated as microgram of gallic acid equivalent per milligram of dry weight ( $\mu \mathrm{g}$ GAE/mg dry weight) by using a gallic acid calibration curve.

\subsection{Anti-Oxidant Assays}

\subsubsection{DPPH Radical Scavenging Assay}

The free radical scavenging activity of the extract was measured by 1,1-diphenyl-2picrylhydrazyl (DPPH) assay [25] with slight modifications. The extract was prepared in ethanol to various concentrations. Each of these sample solutions $(75 \mu \mathrm{L})$ was separately mixed with $150 \mu \mathrm{L}$ of $0.2 \mathrm{mM}$ DPPH solution. L-Ascorbic acid was used as a positive control. The reaction mixture was incubated at room temperature for $30 \mathrm{~min}$ in the dark, and the absorbance was measured at $517 \mathrm{~nm}$ using a microplate reader. Ethanol was used as the blank. A percentage of DPPH radical scavenging activity was calculated using the following equation:

$$
\text { The percentage of scavenging activity }(\%)=[1-(\mathrm{A} / \mathrm{B})] \times 100
$$

where A is the absorbance of DPPH solution mixed with the test sample and B is the absorbance of DPPH solution mixed with ethanol (blank). The concentration yielding 50\% free radical scavenging capacity $\left(\mathrm{IC}_{50}\right)$ is reported.

\subsubsection{ABTS Radical Cation Decolorization Assay (ABTS Assay)}

2,2-Azino-bis-(3-ethylbenzothiazoline-6-sulfonic acid) (ABTS) radical cation scavenging activity of the extract was conducted according to the method described by a previous study [26] with slight modifications. Briefly, $7 \mathrm{mM}$ of ABTS was prepared. The ABTS solution was mixed with $2.45 \mathrm{mM}$ potassium persulfate and incubated at room temperature for $16-18 \mathrm{~h}$ in the dark to generate $\mathrm{ABTS}^{\bullet+}$. Then, the solution was diluted with ethanol to an absorbance of $0.70 \pm 0.02$ at $750 \mathrm{~nm}$. A stock solution of the extract was prepared in ethanol. L-Ascorbic acid was used as a positive control. The ABTS assay was conducted by mixing $200 \mu \mathrm{L}$ of the diluted $\mathrm{ABTS}^{\bullet+}$ solution with $20 \mu \mathrm{L}$ of the test sample. This reaction mixture was incubated in the dark at room temperature for $10 \mathrm{~min}$, and the absorbance was assessed at $734 \mathrm{~nm}$ using a microplate reader. A percentage of ABTS radical cation decolorizing activity was calculated in a similar manner to DPPH assay.

\subsubsection{Ferric Reducing Antioxidant Power Assay (FRAP Assay)}

Ferric reducing antioxidant power (FRAP) assay was conducted according to the FRAP assay method [27] with slight modifications. Firstly, the FRAP solution was prepared by mixing $300 \mathrm{mM}$ acetate buffer ( $\mathrm{pH}$ 3.6), $10 \mathrm{mM}$ 2,4,6-tri-2-pyridyl-2-triazine (TPTZ) solution and $20 \mathrm{mM}$ ferric chloride at a ratio of 10:1:1. The FRAP solution $(200 \mu \mathrm{L})$ was mixed with $20 \mu \mathrm{L}$ of the test sample. L-Ascorbic acid was used as a positive control. The reaction mixture was incubated at $37^{\circ} \mathrm{C}$ for $30 \mathrm{~min}$, and the absorbance was measured immediately at $570 \mathrm{~nm}$. Ferric reducing antioxidant power was calculated in a similar manner to DPPH assay.

\subsubsection{Nitric Oxide (NO) Radical Scavenging Assay}

The scavenging effects of the extract NO production were estimated according to the method described by a previous study [28] with slight modifications. Various solution concentrations of the extract were prepared by dissolving in ethanol. Briefly, $10 \mathrm{mM}$ sodium nitroprusside (SNP) solution $(60 \mu \mathrm{L})$ was freshly prepared in phosphate buffer 
saline ( $\mathrm{pH} 7.4$ ) as well as $60 \mu \mathrm{L}$ of one of the various concentrations of the test sample. The mixture was incubated at room temperature for $120 \mathrm{~min}$. Then, $120 \mu \mathrm{L}$ Griess reagent $(1 \%$ $(w / v)$ sulfanilamide in $2.5 \%(v / v) \mathrm{H}_{3} \mathrm{PO}_{4}$ and $0.1 \%(w / v) \mathrm{N}$-(1-naphthyl)ethylenediamine dihydrochloride (NED) in $\left.2.5 \%(v / v) \mathrm{H}_{3} \mathrm{PO}_{4}\right)$ was added to the mixed solution, which was incubated at room temperature for $10 \mathrm{~min}$. The incubated solution was measured for absorbance at $550 \mathrm{~nm}$. L-Ascorbic acid was used as a positive control. The percentage of nitric oxide radical scavenging activity in a similar manner of DPPH assay.

\subsection{Anti-Bacterial Activity Assays}

C. acnes DMST 14916, S. aureus DMST 8840 and S. epidermidis DMST 15505 were used in this study. The cultures were obtained from the culture collection of the Cosmetics and Natural Products Research Center, Faculty of Pharmaceutical Sciences, Naresuan University, Phitsanulok, Thailand.

\subsubsection{Disc Diffusion Method}

As recommended by the 2013 Clinical and Laboratory Standards Institute guidelines (Clinical and Laboratory Standards Institute, 2013), the concentration of the strain was adjusted to yield approximately $1 \times 10^{8} \mathrm{CFU} \mathrm{mL}{ }^{-1}$ by direct colony suspension method. The bacterial suspension was then evenly spread onto the agar surface. After that, $20 \mu \mathrm{L}$ of the stock solution of the extract $\left(100 \mathrm{mg} \mathrm{mL}^{-1}\right)$ was pipetted onto a sterile paper disc (the amount of test sample was $2 \mathrm{mg} \mathrm{disc}^{-1}$ ). After drying, the disc was placed on the agar surface. For C. acnes, the inoculated Brain Heart Infusion (BHI) (HiMedia, Mumbai, India) agar plate was incubated at $37^{\circ} \mathrm{C}$ under anaerobic conditions for $72 \mathrm{~h}$. In contrast, the inoculated Mueller Hinton agar (MHA) (HiMedia, Mumbai, India) plates of S. epidermidis and S. aureus were incubated for $48 \mathrm{~h}$. Clindamycin disc $\left(2 \mu \mathrm{g} \mathrm{disc}{ }^{-1}\right)$ was used as a positive control for $C$. acnes, and Tetracycline $\left(30 \mu \mathrm{g} \mathrm{disc}{ }^{-1}\right)$ was used as a positive control for S. epidermidis and S. aureus. DMSO was used as a negative control.

\subsubsection{Broth Macrodilution Method}

Two-fold serial dilutions of the extract solution were prepared in isopropyl myristate (IPM) $+10 \%(v / v)$ Tween 80 to obtain a final concentration range of the extract of $0.09-200.00 \mathrm{mg} \mathrm{mL}^{-1}$. For each dilution, $500 \mu \mathrm{L}$ of that dilution was placed into a test tube and combined with $50 \mu \mathrm{L}$ of stains suspension. The final concentration of stains suspension was $1 \times 10^{5} \mathrm{CFU} \mathrm{mL}{ }^{-1}$. The tubes were incubated at $37^{\circ} \mathrm{C}$ under anaerobic conditions for $72 \mathrm{~h}$. These tubes were then used to determine the minimum inhibitory concentration (MIC) of the extract. The MIC is defined as the lowest concentration of the extract that inhibits at least $90 \%$ of bacterial growth, while the minimum bactericidal concentration $(\mathrm{MBC})$ is the lowest concentration of the extract that completely kills the observed bacteria. In order to determine the $\mathrm{MBC}, 10 \mu \mathrm{L}$ of the final contents were taken from each tube used during the MIC procedure and transferred to BHI agar plate for $C$. acnes or MHA plate for S. epidermidis and S. aureus. The plates were then incubated at $37^{\circ} \mathrm{C}$ under anaerobic conditions for 48-72 $\mathrm{h}$. Each stains suspension combined with medium and IPM $+10 \%$ $(v / v)$ Tween 80 was used as a control.

\subsection{Anti-Inflammatory Activities \\ 2.7.1. Cell Culture}

The murine macrophage cell line RAW 264.7 (ATCC, Manassas, VA, USA) was seeded in 96 well-plates at a density of $1.5 \times 10^{5}$ cells well $^{-1}$ in RPMI-1640 (GIBCO, Paisley, UK) supplemented with 10\% $(v / v)$ fetal bovine serum (GIBCO, Paisley, UK) and 1\% $(v / v)$ penicillin/streptomycin (GIBCO, Paisley, UK). Cells were grown at $37^{\circ} \mathrm{C}$ in a humidified $5 \% \mathrm{CO}_{2}$ atmosphere under standard conditions. 


\subsubsection{Cytotoxicity}

RAW 264.7 macrophages at a density of $1.5 \times 10^{5}$ cells well $^{-1}$ were cultured for $24 \mathrm{~h}$. The extract at various concentrations ranging from 0 to $100 \mu \mathrm{g} \mathrm{mL}^{-1}$ were treated after incubation. DMSO was used as vehicle control. The treated cells were incubated for an additional $24 \mathrm{~h}$ and the spent medium was then removed and $200 \mu \mathrm{L}$ of MTS reagent (Abcam, MA, USA) was added to each well and incubated at $37^{\circ} \mathrm{C}$ in a $\mathrm{CO}_{2}$ incubator for $4 \mathrm{~h}$. The absorbance for each well was detected at $492 \mathrm{~nm}$ using a microplate reader.

\subsubsection{Inhibition of NO Production and Pro-Inflammatory Cytokines}

RAW 264.7 macrophages at a density of $1.5 \times 10^{5}$ cells well $^{-1}$ were treated with the test sample in the presence of LPS $\left(1 \mu \mathrm{g} \mathrm{mL}^{-1}\right)$ for $24 \mathrm{~h}$. The conditioned culture media was then collected and centrifuged at $1620 \times g$ in a refrigerated centrifuge at $4{ }^{\circ} \mathrm{C}$ for $10 \mathrm{~min}$. The supernatant was measured for nitrite levels by the Griess assay [29]. Optical density was measured at $550 \mathrm{~nm}$. Data were expressed as the percentage of nitrite levels relative to the nitrite obtained from DMSO control in LPS-treated cells. In another experiment, culture media was examined for the presence of mouse TNF- $\alpha$ (Invitrogen, Vienna, Austria) by enzyme-linked immunosorbent assay (ELISA) according to the manufacturers' specifications. Inflammatory cytokine levels were determined against standard curves.

\subsection{Anti-Tyrosinase Assay}

Tyrosinase inhibitory activity was determined according to the method as previously described [30] with modifications. Briefly, the assays were performed in 96-well plates as follows. Firstly, $150 \mu \mathrm{L}$ of a solution of mushroom tyrosinase $\left(333 \mathrm{U} \mathrm{mL}^{-1}\right)$ in phosphate buffer $(50 \mathrm{mM}, \mathrm{pH} 6.8)$ was distributed in each well, together with $20 \mu \mathrm{L}$ of samples diluted at various concentrations in ethanol. Kojic acid was used as the positive control and ethanol was used as the negative control. The plate was filmed and incubated at room temperature for $5 \mathrm{~min}$. Then, $100 \mu \mathrm{L}$ of a solution of $2 \mathrm{mM}$ 3,4-dihydroxyphenylalanine (L-DOPA) in phosphate buffer $(\mathrm{pH}=6.8)$ were distributed in each well. After 40 min of incubation, the absorbance was performed at $492 \mathrm{~nm}$ to assess the percentage of inhibition using the equation below:

The percentage of tyrosinase inhibition $(\%)=\{[(\mathrm{A}-\mathrm{B})-(\mathrm{C}-\mathrm{D})] /(\mathrm{A}-\mathrm{B})\} \times 100$

where $\mathrm{A}$ is the absorbance of the control with the enzyme, $\mathrm{B}$ is the absorbance of the control without the enzyme, $C$ is the absorbance of the test sample with the enzyme and $D$ is the absorbance of the test sample without the enzyme.

\subsection{Statistical Analysis}

Data were obtained from three independent experiments in triplicates, were expressed as means $\pm \mathrm{SD}$ and analyzed by Student's $t$-test. The $\mathrm{IC}_{50}$ value was determined from a dose-response curve using Microsoft Excel and GraphPad Prism ${ }^{\mathrm{TM}} 7$ software (Graph Pad Software Inc., San Diego, CA, USA).

\section{Results and Discussion}

\subsection{Extraction}

The dry powder of the M. ferrea flowers was extracted by the hydroalcoholic maceration method. The extractive yield of this ethanolic extract was $11.20 \%$.

\subsection{Total Phenolic Contents and Anti-Oxidant Activities}

Reactive oxygen species (ROS), including singlet oxygen, superoxide anion, hydroxyl radical, hydrogen peroxide, lipid peroxide and NO, are subsequently generated from the hypercolonization of $C$. acnes [31]. The DPPH and ABTS assays measure the anti-oxidant potency using a single-electron transfer mechanism [32], while FRAP assay measures the reduction of ferric iron $\left(\mathrm{Fe}^{3+}\right)$ to ferrous iron $\left(\mathrm{Fe}^{2+}\right)$ in the presence of anti-oxidants, which is 
commonly used for the analysis of the total anti-oxidant capacity of the extracts [33] and NO can react with superoxide radical to generate the highly reactive molecule, $\mathrm{ONOO}^{-}$, which results in a cascade of harmful events in the body and detects by using Griess reagent [34] The total phenolic contents and the anti-oxidant activities of the ethanol extract of $M$. ferrea flowers are shown in Table 1. The present study showed that the total phenolic content of the $M$. ferrea flower extract was performed using Folin-Ciocalteu method, which was

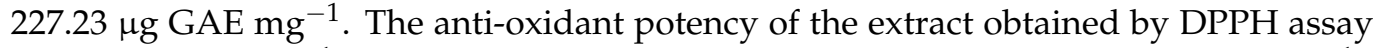
$\left(\mathrm{IC}_{50} 12.87 \mu \mathrm{g} \mathrm{mL}^{-1}\right.$ ) was higher than those obtained by ABTS ( $\mathrm{IC}_{50} 16.95 \mu \mathrm{g} \mathrm{mL}^{-1}$ ), $\mathrm{NO}\left(\mathrm{IC}_{50} 79.83 \mu \mathrm{g} \mathrm{mL}^{-1}\right.$ ) and FRAP $\left(\mathrm{IC}_{50} 96.33 \mu \mathrm{g} \mathrm{mL}^{-1}\right)$ assays, respectively. However, it was less active than the reference compound, L-ascorbic acid, which is known to be a very good anti-oxidant. It is important to note that the $M$. ferrea flower extract is a good anti-oxidant, when compared to the other well-documented polyphenol active plant compounds for its anti-acne properties, such as green tea (Camellia sinensis), pomegranate (Punica granatum) [35-38].

Table 1. Total phenolic contents and anti-oxidant activities of M. ferrea flower extract.

\begin{tabular}{|c|c|c|c|c|c|}
\hline \multirow{2}{*}{ Sample } & \multirow{2}{*}{$\begin{array}{l}\text { Total Phenolic Contents } \\
\quad\left(\mu \mathrm{g} \mathrm{GAE} \mathrm{mg}^{-1}\right)\end{array}$} & \multicolumn{4}{|c|}{ Anti-Oxidant Activities $\left(\mathrm{IC}_{50} \pm \mathrm{SD} ; \mu \mathrm{g} \mathrm{mL^{-1 } )}\right.$} \\
\hline & & DPPH & ABTS & FRAP & NO \\
\hline M. ferrea extract & $227.23 \pm 0.01$ & $12.87 \pm 1.04$ & $16.95 \pm 1.04$ & $96.33 \pm 1.05$ & $79.83 \pm 1.08$ \\
\hline L-Ascorbic acid ${ }^{1}$ & - & $3.46 \pm 1.09$ & $0.86 \pm 1.03$ & $2.06 \pm 1.05$ & $0.35 \pm 1.25$ \\
\hline
\end{tabular}

The results were expressed as mean \pm standard deviation (SD) of triplicate experiments. $(n=3) .{ }^{1} \mathrm{~L}$-Ascorbic acid was used as the positive control.

\subsection{Anti-Bacterial Activity}

C. acnes, S. epidermidis and S. aureus are the Gram-positive anaerobic bacteria that are mostly related to promoting follicular inflammation or inflammatory acne [4]. In this study, the anti-acne bacterial properties of $M$. ferrea flower extract were firstly screened by using the disc diffusion method and the results are shown in Table 2. It was found that the extract showed the strongest inhibitory effect against $C$. acnes, followed by S. epidermidis and S. aureus with the diameters of inhibition zone of $14.33,11.50$ and $9.08 \mathrm{~mm}$, respectively, whereas Clindamycin, the positive control for $C$. acnes and Tetracycline, the positive control for S. epidermidis and S. aureus exhibited the inhibition zones of 60.50, 10.00 and $33.50 \mathrm{~mm}$, respectively. These results showed that the extract was a greater bacterial inhibitory against S. epidermidis than the positive control, while it was relatively weaker activity against C. acnes and S. aureus compared to that of the positive control. In addition, the control disc (DMSO) exhibited no zone of inhibition for all tested bacteria.

Table 2. Anti-bacterial activities of M. ferrea flower extract by the disc diffusion method.

\begin{tabular}{cccc}
\hline \multirow{2}{*}{ Microorganism } & \multicolumn{3}{c}{ Diameter of Inhibition Zone (Mean \pm SD) (mm) } \\
\cline { 2 - 4 } & M. ferrea Flower Extract & Clindamycin $^{\mathbf{1}}$ & Tetracycline $^{\mathbf{2}}$ \\
\hline C. acnes & $14.33 \pm 0.29$ & $60.50 \pm 0.62$ & - \\
S. aureus & $9.08 \pm 0.38$ & - & $33.50 \pm 0.50$ \\
S. epidermidis & $11.50 \pm 0.25$ & - & $10.00 \pm 0.25$ \\
\hline
\end{tabular}

The results were expressed as mean \pm standard deviation (SD) of triplicate experiments. $(n=3) .{ }^{1}$ Clindamycin $\left(2 \mu \mathrm{g} \mathrm{disc}^{-1}\right)$ was used as the positive control for $C$. acnes. ${ }^{2}$ Tetracycline $\left(30 \mu \mathrm{g} \mathrm{disc}^{-1}\right)$ was used as the positive control for S. aureus and S. epidermidis.

After preliminary evaluations, the minimal inhibitory concentration (MIC) and the minimal bactericidal concentration (MBC) of the extract were then evaluated by using broth macrodilution method to determine their bacteriostatic and bactericidal properties. The MIC, the lowest concentration to prevent bacterial growth of the extract on the bacterial growth is shown in Table 3. These results suggested that the values of MIC of the extract $\left(0.78 \mathrm{mg} \mathrm{mL}^{-1}\right)$ on S. epidermidis growth were the lowest among the bacteria tested, suggesting that $S$. epidermidis is more sensitive than C. acnes $\left(3.12 \mathrm{mg} \mathrm{mL}^{-1}\right)$ and S. aureus 
(6.25 mg mL $\mathrm{m}^{-1}$ ). Though, the MBC, the lowest concentration to kill tested organisms, is also shown in Table 3. The most promising activity was displayed against S. epidermidis. The extract was bactericidal against $S$. epidermidis with an $\mathrm{MBC}$ of $1.56 \mathrm{mg} \mathrm{mL}^{-1}$, while the extract was also bactericidal against $S$. aureus and $C$. acnes with consistently lower MBC than S. epidermidis ( 12.50 and $25.00 \mathrm{mg} \mathrm{mL}^{-1}$, respectively). It should be noted that the determinations of MIC and MBC were performed in triplicate for each experiment by using the broth macrodilution method. A serial two-fold dilution of the tested samples was conducted from the stock concentration. In fact, our experiments were confirmed that the breakpoint concentrations of growth inhibition or killed bacteria are the same values in triplicate experiments, which caused S.D. values are 0.00 . These are consistent with previous studies reported [39-44]. According to the ratio MBC/MIC, if the ratio MBC/MIC $\leq 4$, the effect was considered as bactericidal. On the other hand, if the ratio $\mathrm{MBC} / \mathrm{MIC}>4$, the effect was defined as bacteriostatic [39]. The MBC/MIC ratio of the extract is displayed in Table 3. The results showed that the M. ferrea flower extract could be considered as the bactericidal agent against $S$. aureus and S. epidermidis and the bacteriostatic agent against C. acnes.

Table 3. Anti-bacterial activities of $M$. ferrea flower extract by the broth macrodilution method.

\begin{tabular}{cccc}
\hline \multirow{2}{*}{ Microorganism } & \multicolumn{3}{c}{ M. ferrea Flower Extract (Mean $\pm \mathbf{~ S D )}$} \\
\cline { 2 - 4 } & MIC $\left(\mathbf{m g ~ m L}^{-\mathbf{1}}\right)$ & MBC $\left(\mathbf{m g ~ m L}^{-\mathbf{1}}\right)$ & MBC/MIC Ratio \\
\hline C. acnes & $3.12 \pm 0.00$ & $25.00 \pm 0.00$ & 8.01 \\
S. aureus & $6.25 \pm 0.00$ & $12.50 \pm 0.00$ & 2.00 \\
S. epidermidis & $0.78 \pm 0.00$ & $1.56 \pm 0.00$ & 2.00 \\
\hline
\end{tabular}

The results were expressed as mean \pm standard deviation (SD) of triplicate experiments. $(n=3)$.

It has been reported that $S$. epidermidis plays a crucial role in an unfavorable manner of acne by producing the biofilm that stimulates the overgrowth of $C$. acnes. The biofilm protects bacteria from human innate host defense. Additionally, both of S. aureus and S. epidermidis cause skin infection that triggers the inflammatory acne flare-ups [45-47]. Thus, the $M$. ferrea flower extract, which does not only inhibit $C$. acnes growth but also kills S. epidermidis and S. aureus, may provide benefits in the treatment of inflammatory acne such as papules and pustules and reduce bacterial infection, which is the development of abscesses.

\subsection{Anti-Inflammatory Activities}

Inflammation is one of the mechanisms and aspects inducing the formation of acne. Normal sebocytes, the major cell in sebaceous glands, produce just a small quantity of NO and TNF- $\alpha$, but these cytokines are considerably increased when activated by $C$. acnes or LPS. C. acnes can induce the inflammatory response of macrophages or monocytes, leading to the release of proinflammatory cytokines. According to previous studies, proinflammatory cytokines can promote the emergence of skin adhesion molecules and hypersensitivity response with the production of protease, hyaluronidase, and chemotactic factors [2].

In the present study, in order to investigate the effects of the $M$. ferrea flower extract on inflammatory activity, RAW 264.7 cells were stimulated with LPS $\left(1 \mu \mathrm{g} \mathrm{mL}{ }^{-1}\right)$. We first investigated by measuring cell viability using the MTS assay. Treatment of RAW 264.7 cells stimulated by LPS with the extract at a concentration of $25 \mu \mathrm{g} \mathrm{mL}{ }^{-1}$ exerted no effect on cell viability as shown in Figure 1. Therefore, the extract was used at a concentration of $25 \mu \mathrm{g} \mathrm{mL} \mathrm{m}^{-1}$ to investigate its effects on inflammation induced by LPS in RAW 264.7 cells. 


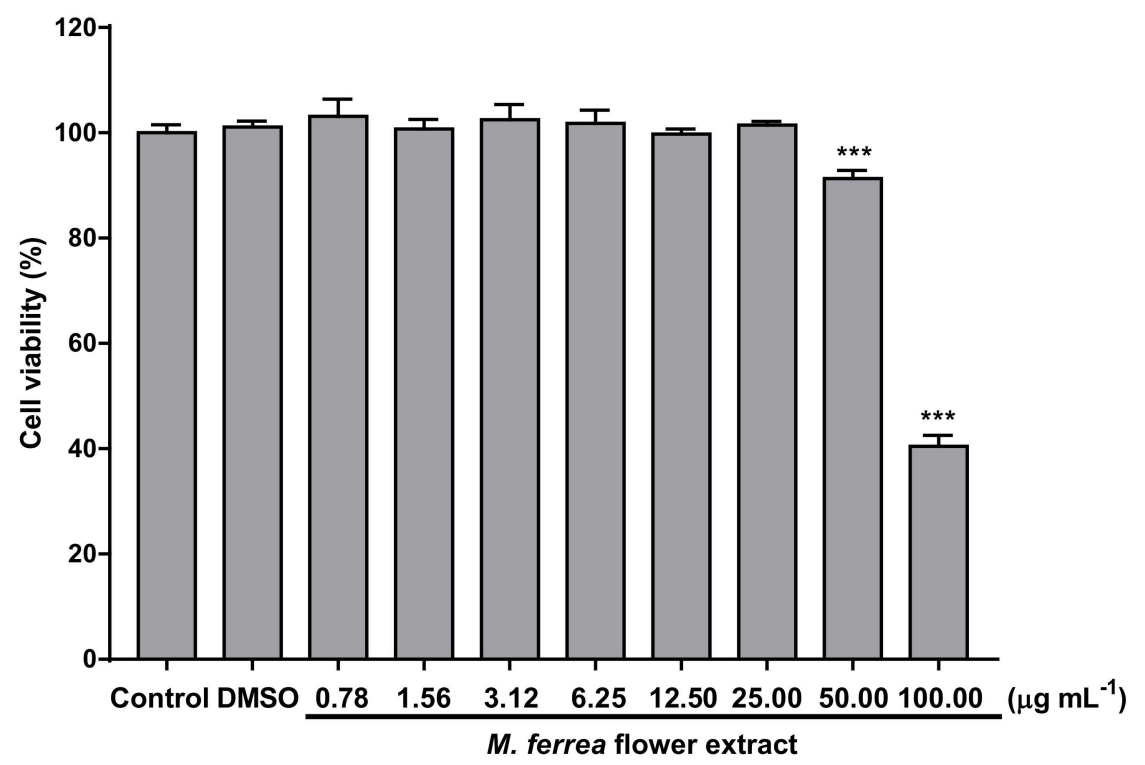

Figure 1. Cytotoxicity of $M$. ferrea flower extract against RAW264.7 macrophage cells. Data are presented as the means $\pm \mathrm{SD} .{ }^{* *} p<0.05$ compared to the control.

The inhibitory effect of the extract on proinflammatory mediator production was investigated by measuring NO levels in RAW 264.7 cells stimulated by LPS. The level of NO in the LPS treated cells group was adjust to $100 \%$ (Figure $2 \mathrm{~A}$ ). The NO production exhibited a statistically significant $(p<0.05)$ increase following stimulation of the cells by LPS $(1.10 \pm 0.34 \%$ for untreated cells group. The $M$. ferrea flower extract at a concentration of $25 \mu \mathrm{g} \mathrm{mL}^{-1}$ accomplished a statistically significant decrease $(p<0.05)$ of NO production in cells stimulated by LPS $(4.40 \pm 0.50 \%)$ compared with the LPS treated cells group.
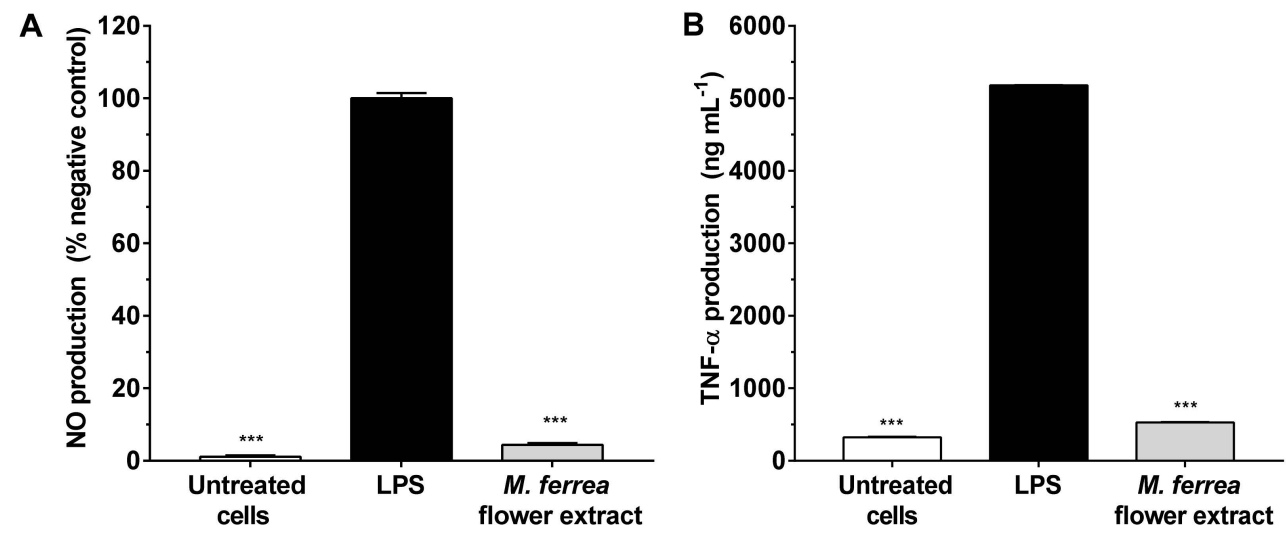

Figure 2. (A) Inhibitory effect of M. ferrea extract on NO production in LPS-induced inflammation in RAW 264.7 macrophage cells, (B) Inhibitory effect of $M$. ferrea extract on LPS-induced TNF- $\alpha$ level in RAW 264.7 macrophage cells. Data are presented as the means \pm SD. ${ }^{* * *} p<0.05$ compared with LPS treated cells only.

To better understand the inhibitory effect of the extract on inflammation, the expression of proinflammatory cytokine TNF- $\alpha$ was investigated in RAW 264.7 cells stimulated by LPS. The expression of TNF- $\alpha$ exhibited a statistically significant increase $(p<0.05)$ following stimulation of the cells treated by LPS $\left(324.08 \pm 12.33 \mathrm{ng} \mathrm{mL}{ }^{-1}\right.$ for untreated cells group and $5180.49 \pm 20.65 \mathrm{ng} \mathrm{mL}^{-1}$ for LPS treated cells group). Treatment with the $M$. ferrea flower extract was associated with inhibition of LPS-induced TNF- $\alpha$ expression in RAW 264.7 cells (Figure 2B). A statistically significant decrease $(p<0.05)$ in the expression of TNF- $\alpha$ at a concentration of $25 \mu \mathrm{g} \mathrm{mL}^{-1}$ extract was observed $\left(528.49 \pm 5.57 \mathrm{ng} \mathrm{mL}{ }^{-1}\right)$ 
compared with the LPS treated cells group, indicating that the $M$. ferrea flower extract inhibits the synthesis of proinflammatory cytokines in activated macrophages.

According to the results, M. ferrea flower extract showed high total phenolic content. The previous study has been reported that the ethanolic $M$. ferrea flower extract contained phenolic compounds, eugenol and cinnamaldehyde, as the major compounds [48]. These compounds have anti-inflammatory effects induced by $C$. acnes $[49,50]$. In addition, $M$. ferrea extract inhibited the growth of $S$. aureus by disruption of the cell membrane [51]. Moreover, plant phenolic compounds are an alternative therapeutic agent to avoid antibiotic-resistant bacteria.

However, the amount of active compounds or plant extracts in topical cosmetic formulations are normally higher than the effective dose determined from cell-based assay. This was due to the active agents incorporated into topical formulations do not easily penetrate through the skin [36,52-56]. The effective concentration for anti-bacteria and anti-inflammatory of $M$. ferrea flower extract obtained from this study conforms to bacteria co-exist on the skin surface, while macrophages are present in skin tissue. Thus, it is the justification for the use of antibacterial effective dose $\left(25 \mathrm{mg} \mathrm{mL}^{-1}\right)$ of $M$. ferrea flower extract in topical formulation and it is likely to be safe and effective for immune cell in skin tissue. However, the effective dose of M. ferrea flower extract incorporated into topical formulation for anti-acne treatment should be further investigated, including the identification of the active compounds in the crude extract, type of formulation, skin permeation, penetration and irritation studies. Further studies are needed to determine their safety and effectiveness, particularly skin permeation and skin irritation (e.g., OECD Test Guidelines 428 and 439).

\subsection{Anti-Tyrosinase Activity}

Melanin is synthesized by the melanocyte, which has essential roles such as influencing skin appearance and improving the body's protection against UV radiation. Melanin synthesis is regulated by numerous enzymes such as tyrosinase and tyrosinase-related proteins, leading to a stimulation of pigmentation. Inflammatory hyperpigmentation such as acne can cause skin darkening and discoloration that appears as spots or large unsightly patches [57]. In order to evaluate the skin lightening effect of the $M$. ferrea flower extract, a mushroom tyrosinase inhibition assay was performed. However, the extract exhibited weak anti-tyrosinase activity, which was less effective than kojic acid, a well-known tyrosinase inhibitor as shown in Table 4.

Table 4. Tyrosinase inhibitory activity of $M$. ferrea flower extract.

\begin{tabular}{cc}
\hline Sample & Anti-Tyrosinase Activity $\left(\mathbf{I C}_{\mathbf{5 0}} \pm \mathbf{S D} ; \boldsymbol{\mu g} \mathbf{~ m L}^{-\mathbf{1}}\right)$ \\
\hline M. ferrea extract & $219.58 \pm 3.41$ \\
Kojic acid $^{1}$ & $46.05 \pm 1.16$ \\
\hline
\end{tabular}

${ }^{1}$ Kojic acid was used as the positive control.

\section{Conclusions}

In this study, the potent anti-acne property of $M$. ferrea flower extract was reported. The extract clearly demonstrated the ability to anti-acne-causing bacteria activities associated with anti-oxidative properties. The anti-inflammatory activities of the extract were also elucidated through the inhibition of inflammatory mediator, NO and pro-inflammatory cytokine, TNF- $\alpha$. In addition, the extract showed some anti-tyrosinase activities, which is beneficial for reducing post-inflammatory hyperpigmentation, even it is lower than that of the reference compound, kojic acid. Therefore, the $M$. ferrea flower extract can be safe and may serve as an alternative natural anti-acne agent for uses in topical cosmeceutical formulations for the treatment of inflammatory acne. Further experiments to thoroughly explore the bioactivities of isolated chemical constituents of $M$. ferrea flower extract are awaited. 
Author Contributions: Conceptualization, W.N.; methodology, W.N., W.P. and W.S.; software, W.P.; validation, W.N.; formal analysis, V.A. and A.S.; investigation, W.N. and W.P.; resources, W.N. and A.S.; data curation, W.N. and W.P.; writing-original draft preparation, W.N. and W.P.; writingreview and editing, W.S., V.A., B.-e.Y. and A.S.; visualization, W.P.; supervision, A.S., B.-e.Y. and V.A.; project administration, W.N.; funding acquisition, W.N. All authors have read and agreed to the published version of the manuscript.

Funding: This study was funded by Ramkhamhaeng University Research Grant.

Institutional Review Board Statement: Not applicable.

Informed Consent Statement: Not applicable.

Data Availability Statement: Not applicable.

Acknowledgments: This work was supported by Ramkhamhaeng University. Support from the Center of Excellence for Innovation in Chemistry (PERCH-CIC), Ministry of Higher Education, Science, Research and Innovation is gratefully acknowledged.

Conflicts of Interest: The authors declare no conflict of interest.

\section{References}

1. De Canha, M.N.; Komarnytsky, S.; Langhansova, L.; Lall, N. Exploring the anti-acne potential of Impepho [Helichrysum odoratissimum (L.) sweet] to combat Cutibacterium acnes virulence. Front. Pharmacol. 2020, 10, 1559. [CrossRef]

2. Chen, L.-W.; Chung, H.-L.; Wang, C.-C.; Su, J.-H.; Chen, Y.-J.; Lee, C.-J. Anti-acne effects of cembrene diterpenoids from the cultured soft coral Sinularia flexibilis. Mar. Drugs 2020, 18, 487. [CrossRef] [PubMed]

3. Fournière, M.; Latire, T.; Souak, D.; Feuilloley, M.G.J.; Bedoux, G. Staphylococcus epidermidis and Cutibacterium acnes: Two major sentinels of skin microbiota and the influence of cosmetics. Microorganisms 2020, 8, 1752. [CrossRef] [PubMed]

4. Farrar, M.D.; Ingham, E. Acne: Inflammation. Clin. Dermatol. 2004, 22, 380-384. [CrossRef] [PubMed]

5. Jin, S.; Lee, M.-Y. Kaempferia parviflora extract as a potential anti-acne agent with anti-inflammatory, sebostatic and antipropionibacterium acnes activity. Int. J. Mol. Sci. 2018, 19, 3457. [CrossRef]

6. Srihaphon, K.; Wongwat, T.; Lamlertthon, S.; Pitaksuteepong, T. Investigation on the potential application of Morus alba stem extract for inflammatory acne vulgaris. Songklanakarin J. Sci. Technol. 2020, 42, 1319-1325.

7. Lee, J.W.; Kang, Y.J.; Choi, H.K.; Yoon, Y.G. Fractionated coptis chinensis extract and its bioactive component suppress Propionibacterium acnes-stimulated inflammation in human keratinocytes. J. Microbiol. Biotechnol. 2018, 28, 839-848. [CrossRef]

8. Kanlayavattanakul, M.; Lourith, N. Therapeutic agents and herbs in topical application for acne treatment. Int. J. Cosmet. Sci. 2011, 33, 289-297. [CrossRef] [PubMed]

9. Lalla, J.K.; Nandedkar, S.Y.; Paranjape, M.H.; Talreja, N.B. Clinical trials of ayurvedic formulations in the treatment of acne vulgaris. J. Ethnopharmacol. 2001, 78, 99-102. [CrossRef]

10. Griffith, G.; Trueman, L.; Crowther, T.; Thomas, B.; Smith, B. Onions-A global benefit to health. Phytother. Res. 2002, 16, 603-615. [CrossRef] [PubMed]

11. Van Wyk, B.E. A broad review of commercially important southern African medicinal plants. J. Ethnopharmacol. 2008, 119, 342-355. [CrossRef] [PubMed]

12. Raman, A.; Weir, U.; Bloomfield, S.F. Antimicrobial effects of tea tree oil and its major components on Staphylococcus aureus, S. epidermidis and Propionibacterium acnes. Lett. Appl. Microbiol. 1995, 21, 242-245. [CrossRef]

13. Smitinand, T. Thai Plant Names; Revised Edition; Office of the Forest Herbarium, Department of Natural Park, Wildlife and Plant Conservation: Bangkok, Thailand, 2014; p. 376.

14. Bunyapraphatsara, N.; Chokchaicharoenporn, O. Indigenous Medicinal Herbs; Prachachon: Bangkok, Thailand, $1999 ;$ pp. 534-537.

15. Kshirsagar, P.R.; Patil, S.M. Phytochemistry and pharmacology of Mesua ferrea L. In Bioactive Compounds in Underutilized Fruits and Nuts; Murthy, H., Bapat, V., Eds.; Reference Series in Phytochemistry; Springer: Cham, Switzerland, 2020; pp. $223-256$.

16. Govindachari, T.R.; Pai, B.R.; Subramaniam, P.S.; Rao, U.R.; Muthukumaraswa, N. Constituents of Mesua ferrea L.-mesuaxanthone A and mesuaxanthone B. Tetrahedron 1967, 23, 243-248. [CrossRef]

17. Teh, S.S.; Ee, G.C.L.; Rahmani, M.; Taufiq-Yap, Y.H.; Go, R.; Mah, S.H. Pyranoxanthones from Mesua ferrea. Molecules 2011, 16, 5647-5654. [CrossRef]

18. Ee, G.C.L.; Teh, S.S.; Rahmani, M.; Taufiq-Yap, Y.H.; Go, R.; Mah, S.H. A new furanoxanthone from the root bark of Mesua ferrea. Lett. Org. Chem. 2012, 9, 457-459.

19. Rasol, N.E.; Naz, H.; Awang, K.; Ridhwan, M.J.M.; Choy, Y.K.; Ismail, N.H. Isomeric polycyclic polyprenylated acylphloroglucinols from the bark of Mesua ferrea (Clusiaceae). Nat. Prod. Commun. 2017, 12, 1283-1286. [CrossRef]

20. Chukaew, A.; Saithong, S.; Chusri, S.; Limsuwan, S.; Watanapokasin, R.; Voravuthikunchai, S.P.; Chakthong, S. Cytotoxic xanthones from the roots of Mesua ferrea L. Phytochemistry 2019, 157, 64-70. [CrossRef]

21. Chahar, M.K.; Sanjaya Kumar, D.S.; Geetha, L.; Lokesh, T.; Manohara, K.P. Mesua ferrea L.: A review of the medical evidence for its phytochemistry and pharmacological actions. Afr. J. Pharm. Pharmacol. 2013, 7, 211-219. [CrossRef] 
22. Asif, M.; Jafari, S.F.; Iqbal, Z.; Revadigar, V.; Oon, C.E.; Majid, A.S.A.; Majid, A.M.S.A. Ethnobotanical and phytopharmacological attributes of Mesua ferrea: A mini review. J. Appl. Pharm. Sci. 2017, 7, 242-251.

23. Rajalakshmi, P.; Vadivel, V.; Ravichandran, N.; Brindha, P. Investigation on pharmacognostic parameters of Sirunagapoo (Mesua ferrea L): A traditional Indian herbal drug. Pharmacogn. J. 2019, 11, 225-230. [CrossRef]

24. Nićiforović, N.; Mihailović, V.; Mašković, P.; Solujić, S.; Stojković, A.; Muratspahić, D.P. Antioxidant activity of selected plant species; potential new sources of natural antioxidants. Food Chem. Toxicol. 2010, 48, 3125-3130. [CrossRef] [PubMed]

25. Gordon, M.H.; Paiva-Martins, F.; Almeida, M. Antioxidant activity of hydroxytyrosol acetate compared with that of other olive oil polyphenols. J. Agric. Food Chem. 2001, 49, 2480-2485. [CrossRef] [PubMed]

26. Gião, M.S.; González-Sanjosé, M.L.; Rivero-Pérez, M.D.; Pereira, C.I.; Pintado, M.E.; Malcata, F.X. Infusions of Portuguese medicinal plants: Dependence of final antioxidant capacity and phenol content on extraction features. J. Sci. Food Agric. 2007, 87, 2638-2647. [CrossRef] [PubMed]

27. Berker, K.I.; Güçlü, K.; Tor, I.; Apak, R. Comparative evaluation of Fe(III) reducing power-based antioxidant capacity assays in the presence of phenanthroline, batho-phenanthroline, tripyridyltriazine (FRAP), and ferricyanide reagents. Talanta 2007, 72, 1157-1165. [CrossRef]

28. Bahiense, J.B.; Marques, F.M.; Figueira, M.M.; Vargas, T.S.; Kondratyuk, T.P.; Endringer, D.C.; Scherer, R.; Fronza, M. Potential anti-inflammatory, antioxidant and antimicrobial activities of Sambucus australis. Pharm. Biol. 2017, 55, 991-997. [CrossRef]

29. Suebsakwong, P.; Chulrik, W.; Chunglok, W.; Li, J.-X.; Yao, Z.-J.; Suksamrarn, A. New triterpenoid saponin glycosides from the fruit fibers of Trichosanthes cucumerina L. RSC Adv. 2020, 10, 10461-10470. [CrossRef]

30. Athipornchai, A.; Niyomtham, N.; Pabuprapap, W.; Ajavakom, V.; Duca, M.; Azoulay, S.; Suksamrarn, A. Potent tyrosinase inhibitory activity of curcuminoid analogues and inhibition kinetics studies. Cosmetics 2021, 8, 35. [CrossRef]

31. Leyden, J.J.; McGinley, K.J.; Vowels, B. Propionibacterium acnes colonization in acne and non-acne. Dermatology 1998, 196, 55-58. [CrossRef]

32. Ozgen, M.; Reese, R.N.; Tulio Jr, A.Z.; Scheerens, J.C.; Miller, A.R. Modified 2,2-azino-bis-3-ethylbenzothiazoline-6-sulfonic acid (ABTS) method to measure antioxidant capacity of selected small fruits and comparison to ferric reducing antioxidant power (FRAP) and 2,2'-diphenyl-1-picrylhydrazyl (DPPH) methods. J. Agric. Food Chem. 2006, 54, 1151-1157. [CrossRef]

33. Gliszczyńska-Świgło, A. Antioxidant activity of water soluble vitamins in the TEAC (Trolox equivalent antioxidant capacity) and the FRAP (ferric reducing antioxidant power) assays. Food Chem. 2006, 96, 131-136. [CrossRef]

34. Kwon, S.H.; Wang, Z.; Hwang, S.H.; Kang, Y.-H.; Lee, J.-Y.; Lim, S.S. Comprehensive evaluation of the antioxidant capacity of Perilla frutescens leaves extract and isolation of free radical scavengers using step-wise HSCCC guided by DPPH-HPLC. Int. J. Food Prop. 2017, 20, 921-934. [CrossRef]

35. He, J.; Xu, L.; Yang, L.; Wang, X. Epigallocatechin gallate is the most effective catechin against antioxidant stress via hydrogen peroxide and radical scavenging activity. Med. Sci. Monit. 2018, 24, 8198-8206. [CrossRef] [PubMed]

36. Yoon, J.Y.; Kwon, H.H.; Min, S.U.; Thiboutot, D.M.; Suh, D.H. Epigallocatechin-3-gallate improves acne in humans by modulating intracellular molecular targets and inhibiting P. acnes. J. Investig. Dermatol. 2013, 133, 429-440. [CrossRef] [PubMed]

37. Phimnuan, P.; Yakaew, S.; Yosboonruang, A.; Luangbudnak, W.; Grandmottet, F.; Viyoch, J. Development of anti-acne film from bio-cellulose incorporating Punica granatum peel extract. Walailak J. Sci. Technol. 2018, 16, 765-778. [CrossRef]

38. Lee, C.J.; Chen, L.G.; Liang, W.L.; Wang, C.C. Multiple activities of Punica granatum Linne against acne vulgaris. Int. J. Mol. Sci. 2017, 18, 141. [CrossRef] [PubMed]

39. Mogana, R.; Adhikari, A.; Tzar, M.N.; Ramliza, R.; Wiart, C. Antibacterial activities of the extracts, fractions and isolated compounds from Canarium patentinervium Miq. against bacterial clinical isolates. BMC Complement. Med. Ther. 2020, 20, 55. [CrossRef]

40. Jiamboonsri, P.; Pithayanukul, P.; Bavovada, R.; Chomnawang, M.T. The inhibitory potential of Thai mango seed kernel extract against methicillin-resistant Staphylococcus aureus. Molecules 2011, 16, 6255-6270. [CrossRef]

41. Belay, D.; Kenubih, A.; Yesuf, M.; Kebede, E.; Yayeh, M.; Birhan, M. Antioxidant and antimicrobial activity of solvent fractions of Calpurnia aurea (Ait.) Benth. (Fabaceae). J. Exp. Pharmacol. 2021, 13, 499-509. [CrossRef] [PubMed]

42. Shafiei, Z.; Shuhairi, N.N.; Md Fazly Shah Yap, N.; Harry Sibungkil, C.-A.; Latip, J. Antibacterial activity of Myristica fragrans against oral pathogens. Evid. Based Complement. Alternat. Med. 2012, 2012, 1-7. [CrossRef]

43. Desbois, A.; Lawlor, K. Antibacterial activity of long-chain polyunsaturated fatty acids against Propionibacterium acnes and Staphylococcus aureus. Mar. Drugs 2013, 11, 4544-4557. [CrossRef]

44. Kim, S.; Oh, S.; Noh, H.; Ji, S.; Lee, S.; Koo, J.; Choi, C.W.; Jhun, H.P. In vitro antioxidant and anti-Propionibacterium acnes activities of cold water, hot water, and methanol extracts, and their respective ethyl acetate fractions, from Sanguisorba officinalis L. roots. Molecules 2018, 23, 3001. [CrossRef] [PubMed]

45. Moon, S.H.; Roh, H.S.; Kim, Y.H.; Kim, J.E.; Ko, J.Y.; Ro, Y.S. Antibiotic resistance of microbial strains isolated from Korean acne patients. J. Dermatol. 2012, 39, 833-837. [CrossRef] [PubMed]

46. Lo, C.W.; Lai, Y.K.; Liu, Y.T.; Gallo, R.L.; Huang, C.M. Staphylococcus aureus hijacks a skin commensal to intensify its virulence: Immunization targeting $\beta$-hemolysin and CAMP factor. J. Investig. Dermatol. 2011, 131, 401-409. [CrossRef]

47. Kumar, B.; Pathak, R.; Mary, P.B.; Jha, D.; Sardana, K.; Gautam, H.K. New insights into acne pathogenesis: Exploring the role of acne-associated microbial populations. Dermatol. Sin. 2016, 34, 63-74. [CrossRef] 
48. Hajlaoui, H.; Arraouadi, S.; Noumi, E.; Aouadi, K.; Adnan, M.; Khan, M.A.; Kadri, A.; Snoussi, M. Antimicrobial, antioxidant, anti-acetylcholinesterase, antidiabetic, and pharmacokinetic properties of Carum carvi L. and Coriandrum sativum L. essential oils alone and in combination. Molecules 2021, 26, 3625. [CrossRef]

49. Peker, E.G.G.; Kaltalioglu, K. Cinnamaldehyde and eugenol protect against LPS-stimulated oxidative stress and inflammation in Raw 264.7 cells. J. Food Biochem. 2021, e13980. [CrossRef]

50. Tsai, T.H.; Huang, W.C.; Lien, T.J.; Huang, Y.H.; Chang, H.; Yu, C.H.; Tsai, P.J. Clove extract and eugenol suppress inflammatory responses elicited by Propionibacterium acnes in vitro and in vivo. Food Agric. Immunol. 2017, 28, 916-931. [CrossRef]

51. Aruldass, C.; Marimuthu, M.; Ramanathan, S.; Mansor, S.; Murugaiyah, V. Effects of Mesua ferrea leaf and fruit extracts on growth and morphology of Staphylococcus aureus. Microsc. Microanal. 2013, 19, 254-260. [CrossRef]

52. Lademann, J.; Richter, H.; Jacobi, U.; Patzelt, A.; Hueber-Becker, F.; Ribaud, C.; Benech-Kieffer, F.; Dufour, E.K.; Sterry, W.; Schaefer, H.; et al. Human percutaneous absorption of a direct hair dye comparing in vitro and in vivo results: Implications for safety assessment and animal testing. Food Chem. Toxicol. 2008, 46, 2214-2223. [CrossRef] [PubMed]

53. Novilla, A.; Djamhuri, D.S.; Nurhayati, B.; Rihibiha, D.D.; Afifah, E.; Widowati, W. Anti-inflammatory properties of Oolong tea (Camellia sinensis) ethanol extract and epigallocatechin gallate in LPS-induced RAW 264.7 cells. Asian Pac. Trop. Biomed. 2017, 7, 1005-1009. [CrossRef]

54. Shin, S.; Lee, J.-A.; Son, D.; Park, D.; Jung, E. Anti-skin-aging activity of a standardized extract from Panax ginseng leaves in vitro and in human volunteer. Cosmetics 2017, 4, 18. [CrossRef]

55. Escobar, S.; Valois, A.; Nielsen, M.; Closs, B.; Kerob, D. Effectiveness of a formulation containing peptides and vitamin C in treating signs of facial ageing: Three clinical studies. Int. J. Cosmet. Sci. 2021, 43, 131-135. [CrossRef] [PubMed]

56. Rattanawiwatpong, P.; Wanitphakdeedecha, R.; Bumrungpert, A.; Maiprasert, M. Anti-aging and brightening effects of a topical treatment containing vitamin $\mathrm{C}$, vitamin $\mathrm{E}$, and raspberry leaf cell culture extract: A split-face, randomized controlled trial. J. Cosmet. Dermatol. 2020, 19, 671-676. [CrossRef] [PubMed]

57. Kang, M.C.; Lee, J.-W.; Lee, T.H.; Subedi, L.; Wahedi, H.M.; Do, S.-G.; Shin, E.; Moon, E.-Y.; Kim, S.Y. UP256 inhibits hyperpigmentation by tyrosinase expression/dendrite formation via Rho-dependent signaling and by primary cilium formation in melanocytes. Int. J. Mol. Sci. 2020, 21, 5341. [CrossRef] [PubMed] 